Elżbieta Młyńska

Stowarzyszenie Katechetyków Polskich

\title{
A Catechumenal Model of Catechesis to Prepare Children for First Holy Communion in the Archdiocese of Białystok
}

After the Second Vatican Council, the Church in Białystok became open to the catechetical trend of kerygmatic renewal. Influenced by Her predecessors, the Church began to move away from didactic catechesis and to developing a catechesis based on initiation. Drawing on years of pastoral experience, the Archdiocese of Białystok implemented its own catechetical program that includes scripts and teaching aids based on a catechumenal model of formation to prepare children to receive the Sacraments of Reconciliation and the Eucharist.

Key words: catechesis, parish, catechumenate, initiation, mystagogy, Eucharist, diocesan program.

Since World War II ended, the Archdiocese of Białystok ${ }^{1}$ has always been open to relevant pastoral methods to prepare children for the reception of First Holy Communion. After a period of scholastic catechesis that focused on teaching the catechism, the local church willingly took advantage of the didactic models of teaching that Fr. Józef Wojtukiewicz, ${ }^{2}$ Fr. Wincenty Zaleski, ${ }^{3}$ and later Bishop Edward

$1 \quad$ On June 5, 1991, Pope John Paul II established what is known today as Archdiocese of Białystok. Before 1991, this territory belonged to and was under the administration of the Metropolitan Archdiocese of Vilnius.

2 Cf. J. Wojtukiewicz, Maty katechizm dla przygotowania dzieci do Pierwszej Spowiedzi i Komunii Świętej, Wrocław 1957; B. Rozen, Działalność katechetyczna ks. Józefa Wojtukiewicza w latach 1937-1989, Olsztyn 1999, 131-139.

3 Cf. W. Zaleski, "Przygotowanie do I Spowiedzi i Komunii św. według nowego program," Katecheta 3(1959): 218-227. 
Materski ${ }^{4}$ promoted. However, as soon as the first harbingers of kerygmatic catechesis appeared in Poland after the Second Vatican Council, the Archdiocese of Białystok stayed up to date with the catechetical methods prepared by Fr. Jan Charytański, a Jesuit who focused thematically on the sacraments of Christian initiation. ${ }^{5}$ Fr. Edward Kisiel, who later became the Metropolitan Archbishop of Białystok, was the school inspector at that time. ${ }^{6}$ His successor as diocesan school inspector, Fr. Józef Grygotowicz, continued the same catechetical vision for preparing children for their First Holy Communion in the spirit of the Second Vatican Council. He deepened his knowledge on this topic during his pastoral studies when writing his licentiate thesis,${ }^{7}$ about which he consulted Fr. Franciszek Blachnicki, the main promoter of conciliar renewal in Poland.

Pastoral Theology

\section{The Origin of the Catechumenal Model of Catechesis for First Holy Communion Preparation}

When compared to renewed conciliar theology, pre-conciliar scholastic-didactic catechesis quickly proved to be insufficient. Any form of teaching religion has always aimed to deepen the faith of those being taught; at some point, however, it became evident that catechesis was more concerned with forming the mind and developing certain religious attitudes than leading people into a deeper relationship with Christ and a personal encounter with Him. Such scholastic-didactic catechesis focuses on telling biblical stories and teaching Christian morality by using methods gleaned from schoolteachers. In this context, the changes that took place at the Second Vatican Council were observed with great interest, and they resulted in a renewal of theology and a new vision of pastoral care. The most valuable aspect

$4 \quad$ E. Materski, "Uwagi metodyczne w sprawie przygotowania dzieci do I spowiedzi i Komunii św.," Katecheta 4(1960): 32-43.

5 E. Kisiel, "Katechizacja w Archidiecezji w Białymstoku w latach 1944-1974," Wiadomości Kościelne Archidiecezji Biatostockiej (abbreviated hereafter as WKAB) 4, no. 1(1978): 102-129; J. Charytański, W kręgu zadań i treści katechezy, Kraków 1992, 8; cf. E. Młyńska, "Inicjacja do sakramentu Eucharystii i pokuty klasy I-III," in: Katecheza w parafii. Poszukiwanie tożsamości, ed. K. Kantowski, Warszawa 2004, 28-45.

$6 \quad$ E. Młyńska, L. M. Jakoniuk. "Archbishop Edward Kisiel: The 'Primary Catechist' of the Diocese," in: Rocznik Teologii Katolickiej, XVII/3(2018): 9-23.

7 J. Grygotowicz, "Uroczystość I Komunii świętej w Polsce jako problem pastoralny," in: Eucharystia w duszpasterskie, ed. A. L. Szafrański, Lublin 1977, 255-312. 
conciliar theology was its return to the sources (i.e., the Bible and Church Tradition) and its dialogical nature that points to God and man as interlocutors in this dialogue. Against the backdrop of these psychological and pedagogical trends in catechesis a new kerygmatic catechesis arose. ${ }^{8}$ The basic assumption of this trend is proclaiming the message of salvation, which demands a response on the part of those to whom this message is addressed-in this case, children. ${ }^{9}$ A study version of textbooks prepared in this spirit was created in 1968 and adopted immediately within the Archdiocese of Białystok. Following the textbooks, the Polish Episcopal Conference approved "A Catechetical Program Outline for Primary Schools (Grades I-VIII)," ${ }^{10}$ on May 1, 1972 and simultaneously proposed that two versions of the program be implemented. Fr. Jan Charytański, PhD, prepared the first kerygmatic version, and the second version expanded on Fr. Edward Materski's catechetical models that were already being used. The Archdiocese of Białystok decided to implement the first version because it offered, among other things, teaching manuals and textbooks for students.

In his textbooks, Fr. Jan Charytański proposed two cycles for initiation catechesis-namely, preparation for First Communion in grades I-IV and preparation for confirmation in grades V-VIII. ${ }^{11}$ The catechetical trend that took root in Poland was based on basic tripartite structure that was based primarily on: proclaiming, reflecting on, and living out the Word of God. ${ }^{12}$ From this point forward, catechesis was meant not so much to teach about the Triune God, but to lead the catechized to an encounter with the living God in His Word and in the sacraments. According to this approach, the Bible is treated as the prophetic Divine Word that introduces the listener into the history of salvations and leads him to make acts of faith. Proclaimed in this way, the Word a response on the part of the listener, which leads to dialogue with God.

Kerygmatic catechesis and initiatory catechesis are interconnected. Insofar as word "kerygma" means proclaiming the mystery of Jesus' Passion, Death, and Resurrection and the word "keryx" means "herald," the definition of "initiation" refers to the process of inducting a person into the secrets of the Paschal Mystery. In turn, this mystery

8 T. Panuś, Główne kierunki katechetyczne XX wieku, Kraków 2001, 63-81.

J. Charytański, W kręgu zadań, 169-174.

10 E. Kisiel, "Katechizacja w Archidiecezji w Białymstoku.w latach 1944-1974," WKAB 4, no. 1(1978)

11 J. Charytański, W kręgu zadań, 8.

12 R. Chałupniak, J. Kostorz, Wybrane zagadnienia katechetyki, Opole 2002, 35. 
Pastoral Theology

is celebrated in the sacraments of baptism, Eucharist, and confirmation, which are the necessary in order to belong to the community of the Church. It is for this reason that these are called the sacraments of initiation. ${ }^{13}$

The Eucharistic cycle of catechesis edited by Fr. Charytański was published as four textbooks entitled Bóg z nami [God with Us] and intended for elementary-school children in grades I-IV. At that time, catechesis for children took place within the parish. The main premise of this cycle of Eucharistic catechesis was: 1) to prepare children in grades I-II to receive the sacraments of reconciliation and the Eucharist during the initiation phase,${ }^{14}$ and 2 ) to deepen their sacramental life in the mystagogical phase. ${ }^{15}$ These very assumptions point to the catechumenal nature of this catechesis. This kind of catechesis is meant to lead children to an encounter with God through listening to His Word, and they are then encouraged to respond to God with their lives. It also introduces children to the celebration of the salvific mysteries in the community of the Church. Holy Scripture, the liturgy, the Church, and the Christian life are the primary sources for the content of this catechesis, while the catechists implement methods that correspond to the dialogical character of this catechesis.

This catechetical program was prepared before any relevant Church documents were prepared in Poland, and it introduced the essential ideas of the catechumenate and created a new pastoral and catechetical mentality. Proclamation of the kerygma and initiation into the salvific mysteries are indicative of this catechetical model ${ }^{16}$ that slowly permeated pastoral care. Open to this catechetical trend, the Archdiocese of Białystok slowly implemented its assumptions.

As the kerygma in catechesis boomed, a movement of post-conciliar renewal was taking place within the Church in Poland. Fr. Franciszek Blachnicki, a professor at the Catholic University of Lublin, was behind this movement. He also promoted the same post-conciliar renewal in the Movement of the Living Church, which he founded in the 1960s and

13 Cf. R. Murawski, "Katechumenalny wymiar katechezy - część I," Katecheta 52, no. 2(2008): 7-8.

14 J. Charytański, ed., Bóg z nami. Cz. I. Pierwszy rok wprowadzenia eucharystycznego, Warszawa 1971; Idem, Bóg z nami. Cz. II. Drugi rok wprowadzenia eucharystycznego, Warszawa 1971.

15 J. Charytański, W. Kubik, B. Mokrzycki, eds., Bóg z nami. Cz. III. Pogtębienie życia sakramentalnego Eucharystii i pokuty, Warszawa 1971; Idem, Bóg z nami. Cz. IV. Kościot wspólnota eucharystyczna, Warszawa 1971.

16 Cf. R. Murawski, "Katechumenalny wymiar katechezy - część III," Katecheta 52, no. 4(2008): 11-12. 
in which-as Cardinal Karol Wojtyła noted-he translated the theology of the Second Vatican Council into practical pastoral language. Fr. Blachnicki used the catechumenal models ${ }^{17}$ contained in the document The Rite of Christian Initiation for Adults, which is dedicated to the baptismal catechumenate for adults, ${ }^{18}$ as the basis for the systematic formation of the faithful in the Movement of the Living Church. The process of catechumenal formation is broken down into three steps. The first step is the rite of acceptance into the catechumenate, the second step is election or enrollment of names, and the third step is celebration of the sacraments of initiation. A period of evangelization and pre-catechumenate precede these steps, while a period of mystagogy follows them. The first step is followed by the proper catechumenate. Thus, after evangelization, the individual is admitted into the catechumenate; the catechumenate is then followed by the Rite of Election, which entails admission into the next stages of formation; and after a period of purification and enlightenment, the sacrament of Christian initiation takes place. The proclamation of the Word of God, instruction, and rites called scrutinies and exorcism take place throughout formation. Both the clergy and the laity play a role in the catechumenate. The following are responsible for the catechumenal formation in their own ways: bishops, priests, godparents, and the entire community of the People of God. The catechist is responsible for, among other things, explaining to catechumens the meaning of liturgical symbols connected with the different season of the liturgical year.

Inspired by this document, Fr. Blachnicki proposed postbaptismal formation for different age groups, thereby demonstrating that this model of catechumenal catechesis is universal. A Synod of Polish Bishops confirmed the validity of Fr. Blachnicki's idea in the document "A Message to the People of God" (1977), in which they stated that "the catechumenate is the model for all catechesis" (pg. 8). As a pastoral theologian, Fr. Blachnicki then took on the task of preparing catechesis for first communicants by publishing The Little Catechism, in which he promoted the concept of initiation catechesis, in $1971 .{ }^{19}$

Priests in the Archdiocese of Białystok who were studying pastoral theology with Fr. Blachnicki at the Catholic University of Lublin and

17 Idem, "Katechumenalny wymiar katechezy-część IV, Katecheta 52, no. 6(2008): 6-7.

18 The Latin title of the document is Ordo Initiationis Christianae Adultorum, which is abbreviated as OICA. The Polish edition of this document was published in Katowice in 1988 and is abbreviated as OCWD.

$19 \quad$ F. Blachnicki, Maty katechizm. Przygotowanie do I petnego uczestnictwa we Mszy św. i sakramentu pokuty, Katowice 1971. 
who joined the Movement in the late 1960s absorbed the work of Movement and implemented its style of pastoral ministry in the parishes within the archdiocese. The effect of this ministry was even stronger because laypeople also received formation, which they brought to their parishes when they returned to the diocese. Moreover, laypeople also had easy access to theological studies at the Catholic University of Lublin and at the Academy of Catholic Theology in Warsaw. When studying under the initiators of the kerygmatic renewal in Poland, they spread it in their own way and in their own environments. Because those responsible for catechesis within the archdiocese had personal contact with distinguished catechists who were invited to the catechetical sessions, the influence of the idea of post-conciliar renewal was even stronger. ${ }^{20}$

The new pastoral mentality that was permeated by the spirit of the

Pastoral Theology Second Vatican Council spread slowly throughout Poland until 1990, when it once again became permissible to teach religion in Polish schools. With this change, became necessary to organize catechesis in parishes that paralleled religious education in schools and introduced children to sacramental life. ${ }^{21}$ From this moment forward, the Archdiocese of Białystok began attempts to interpret and address the new challenge and develop programs that would prepare children to receive the sacraments of reconciliation and the Eucharist in their parishes. The Department of Catechesis collaboration with priests and laypersons formed in the Movement of Light and Life animated this effort. ${ }^{22}$ In 1992-1993, the Curia of the Archdiocese of Białystok published a series of articles with the common slogan "Katecheza inicjacyjna [Initiation Catechesis]" in the catechetical monthly publication entitled $\mathrm{Na}$ drogach katechezy [On the Paths of Catechesis]. These articles presented such topics as the liturgical signs and symbols and were addressed to children who were participating in the catechesis on the sacraments. ${ }^{23}$ During the archdiocesan Day of Catechesis that took

$\overline{20} \quad$ Cf. E. Kisiel, "Katechizacja w Archidiecezji w Białymstoku."

21 E. Młyńska, "Formacja eucharystyczna dzieci pierwszokomunijnych w archidiecezji białostockiej," WKAB 35, no. 2(2007): 74-76.

22 Fr. Józef Grygotowicz, Fr. Roman Balunowski, Fr. Jacek Tomkiel, Fr. Zbigniew Snarski, Fr. Andrzej Tałałaj are promoters of the Light and Life Movement and its style for formation. Since 1976, the Ruch Żywego Kościoła (Movement of the Living Churcg) officially changed its name to Ruch Światło-Życie (Light and Life Movement) in 1976.

23 Cf. J. Grygotowicz, "Katecheza inicjacyjna (1): Różaniec," Na drogach katechezy (abbreviated hereafter as NDrK) 1, no. 2(1992):2; Idem, "Katecheza inicjacyjna (7): Eucharystia," NDrK2, no. 4(1993): 6; R. Balunowski, "Katecheza inicjacyjna (2): 
place on September 6, 1977, Fr. Jacek Tomkiel gave a lecture entitled "The Catechumenal Dimension of First Communion Catechesis." All of these efforts led to the development of a document on preparing children for their First Holy Communion. ${ }^{24}$

\section{The Catechumenal Model in Diocesan Catechetical Instruction}

The first documents that laid out the catechumenal model of catechesis on the sacraments in the Archdiocese of Białystok were Dekret dotyczacy przygotowania $i$ udzielania dzieciom sakramentu pokuty $i$ Eucharystii [Decree on Children's Preparation and Reception of the Sacraments of Reconciliation and the Eucharist] as well as Instrukcja duszpastersko-katechetyczna do dekretu $w$ sprawie przygotowania $i$ udzielania dzieciom sakramentów pokuty $i$ Eucharystii [Pastoral and Catechetical Instruction for the Decree on Children's Preparation and Reception of the Sacraments of Reconciliation and the Eucharist], which the Metropolitan Archbishop of Białystok Stanisław Szymecki signed on March 25, 2000. ${ }^{25}$ With the intention to enable children to experience an encounter with Christ in the sacraments of reconciliation and the Eucharist more consciously, the Shepherd of the Archdiocese of Białystok required a three-year cycle of formation for primary school children in grades I-III. In the decree, he also focused on the need to supplement school lessons with liturgical formation by introducing the faith through initiation services. Following the archbishop's indications, the Instruction confirms that intellectual preparation for the reception of the sacraments is insufficient and that it must be supplemented by liturgical formation that takes place over time. The Instruction perceives the need to move away from individual preparation to community formation that is carried out in small groups of children. The entirety of the formation modeled on the catechumenate must include such stages as: thanksgiving celebrated in the local community for the gift of baptism, a deepening of faith by receiving the sacrament of reconciliation before First Holy Communion, and

Książeczka," NDrK 1, no 3(1992): 6; Idem, "Katecheza inicjacyjna (3): Medalik," NDrK 1, no. 4(1992): 4; Idem, “ Katecheza inicjacyjna (5): Światło," NDrK 2, no. 2(1993): 4; Idem, "Katecheza inicjacyjna (6): Nabożeństwo pokutne," NDrK 2 , no. 3(1993): 6; E. Młyńska, "Katecheza inicjacyjna (4): Szata komunijna," NDrK 2, no.1(1993): 6 .

Cf. Archidiecezja Białostocka, Program Archidiecezjalnego Dnia Katechetycznego, NDrK 6, no. 9/61(1997): 11. 
Pastoral Theology

celebrating First Holy Communion as well as the anniversary of one's first full participation in the Eucharist.

The Instruction recommends that parents receive formation at the same time as their children so that they will be able to accompany their children on the path of their encounter with the merciful and Eucharistic Jesus and to know how to support their children in fulfilling their obligations to pray regularly or to refrain from drinking alcohol. In the third class, the instruction contains an indication to prepare parents to teach their children catechetical lessons in mystagogy. The Instruction points out that the catechetical meetings are conducted using liturgical methods such as: celebration, meditation on signs and symbols, adoration, etc. Priests, catechists, and parents and the parish community are response for the formation of children, who they should surround with prayer, which witnesses to the children living faith and an example of commitment to various forms of service.

On September 27, 2004, the Metropolitan of the Archdiocese of Białystok Wojciech Ziemba issued his Komunikat dotyczacy katechezy parafialnej przygotowującej dzieci do I Komunii Św. w Archidiecezji Biatostockiej [Statement on Parish Catechesis that Prepares Children for First Communion in the Archdiocese of Biatystok], ${ }^{26}$ which he addressed directly to parents. In the document, the Shepherd of the archdiocese emphasizes that "the family [...] is the primary and most important place where catechesis is proclaimed." He also recalls that "outside of the family, the parish is the essential community in which religious life is lived out and where it gains its fullness." He then goes on to assert that "the Divine Word is proclaimed, which calls us to conversion; the liturgy is carried out, during which the greatest mystery of our faith is made present; and the community of the baptized prays. In the parish, the community learns to live according to fraternal charity." In: the statement, Archbishop Ziemba informs parents that "catechesis that serves to deepen the life of faith is continuous and, for this reason, catechetical meetings are held in the parish throughout grades I, II, III. In first grade, the liturgical meetings remind children that they belong to the Church through holy baptism. In second grade, [children] are prepared directly to receive the sacraments of reconciliation and the Eucharist. And in third grade, [children] deepen their Eucharistic life. At the end, the archbishop invites parents to accompany their

26 Document 669/04 can be found in the Archiwum Wydziału Katechetycznego Kurii Metropolitalnej Białostockiej [Archives of the Archdiocese of Białystok Curia's Department of Catechesis]. Abbreviated hereafter as Arch. WK KMB. 
children in parish catechesis and support them through the witness of their faith.

In addition to the archbishop's aforementioned message, which contained the main ideas of parish catechesis, the Curia of the Archdiocese of Białystok prepared the document Instrukcję duszpasterskokatechetyczna dotyczaca przygotowania i udzielania dzieciom sakramentów pokuty $i$ Eucharystii [Pastoral and Catechetical Instruction on Preparing Children to Receive the Sacraments of Penance and Eucharist], which the director of the Department for Catechesis, Fr. Józef Grygotowicz, signed on August 31, 2005. ${ }^{27}$

In accordance with the Dyrektorium Ogólnego o Katechizacji [General Directory for Catechesis] from 1997, which calls the parish the privileged place for catechesis (p.107), the Instrukcje duszpasterskokatechetyczna dotyczaca przygotowania i udzielania dzieciom sakramentów pokuty $i$ Eucharystii [Pastoral and Catechetical Instruction to Prepare and Impart to Children the Sacraments of Penance and Eucharist] recommends that children be prepared for the sacraments of penance and the Eucharist in the parishes where they reside. The diocesan document states that, as a rule, preparation for these sacraments cannot be a single pastoral act, but rather should involve children in ongoing formation for the baptized so that they can mature in their faith. According to this principle, catechesis for children should take place both before and after they have received the sacraments of reconciliation and the Eucharist. It is for this reason that catechesis lasts three years.

The course of catechetical formation proposed in the Instruction published in 2005 assumes that children who are baptized as infants will receive their First Holy Communion. Therefore, catechesis for grade I is treated like a time for "Thanksgiving for the gift of faith and being children of God." This is a period of mystagogy in relation to the baptism that the children received as infants. Liturgical catechesis should be based on baptismal signs. In turn, catechesis for second graders involves preparing the children to participate in the sacraments of confession and the Eucharist. This stage of preparation is called "Wtajemniczenie $w$ sakrament Eucharystii oraz Pokuty $i$ Pojednania [Initiation into Mysteries of the Sacraments of the Eucharist as well as Penance and Reconciliation]. This catechesis should initiate children into the divine mystery of forgiveness as well as the sacrificial love of Jesus Christ that is celebrated in the Eucharist. Initiation into these sacraments should take the form of a penitential celebrations 
and initiation Masses. Furthermore, catechesis during the third grade aims to continue the children's sacramental life and deepen their intimacy with God. This stage of formation is called Pogtębienie zycia $w$ duchu sakramentu pokuty $i$ Eucharystii [A Deeper Life in the Spirit of the Sacraments of Reconciliation and the Eucharist]. According to the Instruction's indications, formation is connected with the liturgical year. Catechesis in the third grade should introduce children to active and full participation in the Sunday liturgy of the Eucharist and emphasize its cyclical character. Therefore, it should include instruction in liturgical music and songs, the liturgical symbols corresponding to the holy days celebrated by the Church, as well as preparation for some forms of liturgical service. In order to deepen the children's penitential formation, instructors should introduce them to First Friday devotions.

Parents are invited to receive formation during all of the stages of

Pastoral Theology their children's preparation, which should familiarize them with the children's program, its content, and activities. The parents are encouraged to participate with their children in monthly parish meetings, to practice and expose their children to Christian customs at home, and to be witnesses of mature faith for their children on a daily basis. The Instruction also values the role of the school environment, stating that it is "an excellent place to come to know the faith and be formed in religious and moral attitudes." This, however, is the parish community's greatest responsibility, including priests, catechists, and animators who are formed in movements.

The document described briefly above was another factor that influenced the process of implementing a catechumenal model of parish catechesis within the Archdiocese of Białystok. Fr. Jacek Tomkiel, the pastor of the newly erected parish of Mother Bolesława Lament in Białystok, played an active role in co-designing and promoting this model. ${ }^{28}$ Formed in the Light and Life Movement as well as the Pastoral and Liturgical Institute at the Catholic University of Lublin, he learned-as he himself says - to love the liturgy. For this reason, as a pastor he enthusiastically and committedly introduced the recommendations for the diocesan instructions that he himself co-wrote. In this way, he brought to completion the formation that he received in the school of Servant of God Fr. Franciszek Blachnicki, Fr. Wojciech Danielski, and the many other Polish liturgists who collaborated with them. Putting theory into practice, he readily drew on the rich pastoral experience of Fr. Stanisław Hartlieb from the parish in Konarzewo

$28 \quad$ Por. J. Tomkiel, "Katecheza pierwszokomunijna - nowa szansa dla duszpasterstwa - świadectwo," WKAB 35, no. 2(2007): 64-67. 
in the Archdiocese of Poznan. For decades, he brought the French experience of the catechumenate to Poland and, in this same spirit, prepared the children in his parish to receive the sacraments. Drawing on his years of experience, Fr. Jacek Tomkiel published a book entitled Pierwsza Komunia święta - droga wtajemniczenia $w$ paschę Chrystusa [First Holy Communion: The Path of Initiation into Christ's Paschal Meal $]^{29}$ and created an original and innovative program for this kind of catechesis. Among other things, he proposed that children receive the sacrament of reconciliation twice before their First Holy Communion. This pastoral decision was motivated by the conviction that children should not be filled with fear and emotional tension by making their first confession on the day before their First Holy Communion. In addition, he believed that the sacrament of reconciliation should not serve as a kind of "permit' that allows one to receive the Body of Christ, but rather should be in itself a form of Communion, since through the sacrament the individual is united with God and others. Moreover, Fr. Tomkiel points out that the celebration of the solemn liturgy for First Holy Communion had been purified of rites that had previously been in use. He is of the opinion, therefore, that it is not necessary for the individual to renew their baptismal promises or for the baptismal candle to be lit during the celebration of First Holy Communion. Rather, parents should be sure to bless their children at home before leaving for the church and sprinkle them with holy water once they arrive. The celebration of First Holy Communion should focus exclusively on the children's full participation. Fr. Andrzej Tałałaj, ${ }^{30}$ who served as a pastor in a village parish, as well as Renata Trochim, ${ }^{31}$ a catechist who prepared village children for their First Holy Communion, also shared about their experiences implementing the archdiocese's Instruction in the 2007 publication of Wiadomości Kościelnych [Church News].

\section{The Catechumenal Model in the Diocesan Materials Entitled "To Meet the Lord Jesus"}

The diocesan catechetical materials being prepared for publication this year (2020) represent the next phase in implementing the

$29 \quad$ This book was published by Wydawnictwo WAM in Kraków in 1996.

$30 \quad$ A. Tałałaj, "O przygotowaniu do I Komunii świętej w parafii wiejskiej,” WKAB 35(2007): 68-70.

$31 \quad$ R. Trochim, "W drodze do sakramentu pokuty i Komunii świętej," WKAB 35(2007): 70-73. 
Pastoral Theology
Instruction. After years of attempts to renew First Communion catechesis in parishes, it was determined that it would be useful to prepare detailed teaching aids to facilitate catechesis. Therefore, from 2011-2014, a team of catechists under the direction of Elżbieta Młyńska edited the scripts for the catechetical meetings with children as well as the outlines of the stages of formation for the parents. The fruits of this work were three booklets that correspond respectively with the three distinct stages of children's formation, a booklet containing the outline of the evangelical examination and revision for the parents, and a separate publication containing the methodological guidelines for catechists. The booklets intended for the children's formation are entitled Bóg nas wota [God Calls Us] for grade I, Biegnę na spotkanie [Eager to Meet Christ] for grade II, and Razem świętujemy [Celebrating Together]. ${ }^{32}$ The authors of these teaching aids intended to capture the dynamics of the catechetical process in these titles. The title Bóg nas wota [God Calls Us] is meant to make the children aware that they belong to the Lord God from the moment of their baptism onward, are His children, and, as such, should desire to encounter Him at church. The monthly meetings focus on the baptismal signs and liturgical symbols that serve as reminders that God resides in the sanctuary of the Church; that God calls them by name; and that God includes them in His family through the sacrament of baptism, cleanses them of their faults, speaks to them through Holy Scripture, gives them Himself in the Eucharistic Bread, gives them His Mother, and blesses them. The title and motto for the second year of formation, Biegne na spotkanie [Eager to Meet Christ] is meant to express the children's readiness to respond to God's love. Second-year formation is dedicated to forming moral attitudes within the children that are naturally connected to preparation for the sacrament of reconciliation. These meetings are intended to integrate the group, allow the children to listen to the Word of God together, and respond to God by living in accordance with His call and through prayer. The third year is entitled Razem świętujemy [Celebrating Together] and involves a series of initiation Masses. By participating in these communal Eucharistic celebrations every month, the children are introduced to the Introductory Rites, the Liturgy of the Word, the Liturgy of the Eucharist, Communion Rites, and Concluding Rites. These Holy Masses celebrated with the children are called initiatory Masses because they gradually help the children understand the Eucharistic liturgy and initiate them into Christ's Paschal Sacrifice. When understood in this way, these Masses move 
beyond the previous way of thinking about the initiation Masses, which included blessing religious objects such as rosaries, prayer books, holy medals, and candles. ${ }^{33}$ This made people associate initiation more with the blessing of items to be used in the liturgy or for private devotion than with the liturgy of the Holy Mass itself. ${ }^{34}$

After a four-year trial, the study version of the materials presented was submitted to the diocesan Catechetical Council to be verified and assessed. The council provided its evaluation and pointed out the materials' shortcomings. ${ }^{35}$ In the meantime, Polish primary schools have undergone reform and have returned to the previously implemented 8-grade education system. As a result, the four-year Eucharistic formation program for children has been offered once again. In this situation, however, it was necessary to expand the proposal for the formation program to include children in grade IV and improve the mystagogy stage. In addition, the reception of the sacraments of reconciliation and the Eucharist, which formerly took place during the second year (grade II) of formation, can be offered over two years (i.e., Penance in grade II, and the Eucharist in grade III).

Since the study materials were lacking in some areas and unable to meet current challenges in catechesis, a commission was called to prepare new materials adapted to the current needs. The new version of the materials that covers four years of formation bears one common title: Na spotkanie $z$ Panem Jezusem [Encountering the Lord Jesus]. ${ }^{36}$ The teaching aids include scripts for the catechetical meetings for grade I, which focus on the sacrament of baptism; for grade II, which focus on the sacrament of reconciliation; for grade III, which focus on the sacrament of the Eucharist; and for grade IV, which contains materials about life in the community of the Church. Individual formation booklets also have their own unique titles that reflect the dynamics of catechumenal initiation catechesis. The title of the first booklet Bóg nas wota [God Calls Us] was changed to Bóg mnie wota [God Calls Me]. This change came about after considering the psychological considerations of children who usually thinks first about themselves and then gradually undergo the process of socialization and begin to think about the community. The titles of the booklets for grades II and III remain unchanged. However, the formation booklet for children in grade IV

\footnotetext{
33 E. Materski, Razem z dzieckiem przeżywamy Rok Pierwszej Komunii Świętej, Sandomierz 1994.

34 E. Młyńska, Inicjacja do sakramentu, 33-34.

35 The meeting took place in July 2018. 
is entitled Kochamy Jezusa [We Love Jesus]. This titles expresses the attitude of mission to which each person is called through receiving Jesus in the sacraments of reconciliation and the Eucharist. During this period of mystagogy, the children are encouraged to encounter Jesus at Sunday Mass and to receive God's mercy by going to confession regularly regularly. Living in friendship with Christ should lead the children to join their respective parish's community of children and, thereby, systematically deepen their faith. The materials for children at every level also include formation materials for the parents. The aim of these materials is to prompt parents to take an active role in their children's formation; for this reason, they include such methodological proposals as, for example, making an evangelical examination and revision of one's life as well as dramas based on the Bible.

The materials used to prepare children to receive their First Holy

Pastoral Theology

Communion in the Archdiocese of Białystok are the result of nearly 50 years of research on this topic. These materials reflect efforts to introduce the catechumenal model of catechesis for children preparing to encounter Christ in First Holy Communion in parishes.

\section{Bibliography:}

1. Balunowski, R. "Katecheza inicjacyjna (2): Książeczka." Na drogach katechezy 1, no. 3(1992): 6.

2. Balunowski, R. "Katecheza inicjacyjna (3): Medalik." Na drogach katechezy 1, no. 4(1992): 4.

3. Balunowski, R. "Katecheza inicjacyjna (5): Światło.” Na drogach katechezy 2, no. 2(1993): 4 .

4. Balunowski, R. "Katecheza inicjacyjna (6): Nabożeństwo pokutne." Na drogach katechezy 2, no. 3(1993): 6

5. Blachnicki, F. Maty katechizm. Przygotowanie do I petnego uczestnictwa we Mszy św. i sakramentu pokuty. Katowice 1971.

6. Charytański, J., ed. Bóg z nami. Cz. I. Pierwszy rok wprowadzenia eucharystycznego. Warszawa 1971.

7. Charytański, J., ed. Bóg z nami. Cz. II. Drugi rok wprowadzenia eucharystycznego. Warszawa 1971.

8. Charytański, J., Kubik, W., Mokrzycki, B., eds. Bóg z nami. Cz. III. Pogłębienie życia sakramentalnego Eucharystii i pokuty. Warszawa 1971.

9. Charytański, J., Kubik, W., Mokrzycki, B., eds. Bóg z nami. Cz. IV. Kościoł wspólnotą eucharystyczna. Warszawa 1971.

10. Charytański, J. W kręgu zadań i treści katechezy. Kraków1992.

11. Chałupniak, R., Kostorz, J. Wybrane zagadnienia katechetyki. Opole 2002.

12. Grygotowicz, J. "Katecheza inicjacyjna (1): Różaniec." Na drogach katechezy 1, no. 2(1992): 2.

13. Grygotowicz, J. "Katecheza inicjacyjna (7): Eucharystia." Na drogach katechezy 2, no. 4(1993): 6. 
14. Grygotowicz, J. "Uroczystość I Komunii świętej w Polsce jako problem pastoralny." In: Eucharystia w duszpasterskie. Edited by A. L. Szafrański. Lublin 1977, 255-312.

15. Kisiel, E. "Katechizacja w Archidiecezji w Białymstoku w latach 19441974." Wiadomości Kościelne Archidiecezji Białostockiej 4, no. 1(1978): 102-129.

16. Materski, E. Razem z dzieckiem przeżywamy Rok Pierwszej Komunii Świętej. Sandomierz 1994.

17. Materski, E. "Uwagi metodyczne w sprawie przygotowania dzieci do I spowiedzi i Komunii św." Katecheta 4(1960): 32-43.

18. Murawski, R. "Katechumenalny wymiar katechezy - część I." Katecheta 52, no. 2(2008).

19. Murawski, R. "Katechumenalny wymiar katechezy - część III." Katecheta 52, no. 4(2008).

20. Murawski, R. "Katechumenalny wymiar katechezy - część IV, Katecheta 52 , no. 6(2008).

21. Młyńska, E. "Formacja eucharystyczna dzieci pierwszokomunijnych w archidiecezji białostockiej." Wiadomości Kościelne Archidiecezji Biatostockiej 35, no. 2(2007).

22. Młyńska, E. "Inicjacja do sakramentu Eucharystii i pokuty klasy I-III.” In: Katecheza w parafii. Poszukiwanie tożsamości. Edited by K. Kantowski. Warszawa 2004, 28-45.

23. Młyńska, E. "Katecheza inicjacyjna (4): Szata komunijna." Na drogach katechezy 2, no.1(1993): 6 .

24. Młyńska, E., Jakoniuk, L. M. "Archbishop Edward Kisiel: The 'Primary Catechist' of the Diocese." In: Rocznik Teologii Katolickiej, XVII/3(2018): 9-23.

25. Panuś, T. Główne kierunki katechetyczne XX wieku. Kraków 2001, 63-81.

26. Rozen, B. Działalność katechetyczna ks. Józefa Wojtukiewicza w latach 1937-1989. Olsztyn 1999.

27. Tałałaj, A. "O przygotowaniu do I Komunii świętej w parafii wiejskiej." Wiadomości Kościelne Archidiecezji Białostockiej 35(2007): 68-70.

28. Tomkiel, J. "Katecheza pierwszokomunijna - nowa szansa dla duszpasterstwa - świadectwo." Wiadomości Kościelne Archidiecezji Biatostockiej 35 , no. 2(2007): 64-67.

29. Trochim, R. "W drodze do sakramentu pokuty i Komunii świętej." Wiadomości Kościelne Archidiecezji Białostockiej 35(2007): 70-73.

30. Wojtukiewicz, J. Maty katechizm dla przygotowania dzieci do Pierwszej Spowiedzi i Komunii Świętej. Wrocław 1957.

31. Zaleski, W. "Przygotowanie do I Spowiedzi i Komunii św. według nowego program." Katecheta 3(1959): 218-227. 